\title{
High prevalence of Miconia chamissois (Melastomataceae) pollen in brood cell provisions of the orchid bee Euglossa townsendi in São Paulo State, Brazil
}

\author{
Cláudia Inês da Silva ${ }^{1,2,3}$, Maurício Meirelles do Nascimento Castro ${ }^{1}$, \\ Isabel Alves dos SANTOS ${ }^{3}$, Carlos Alberto Garófalo ${ }^{1}$ \\ ${ }^{1}$ Faculdade de Filosofia, Ciências e Letras de Ribeirão Preto, Universidade de São Paulo, Avenida Bandeirantes 3900, \\ Ribeirão Preto, SP 14040-901, Brazil \\ ${ }^{2}$ Departamento de Zootecnia, Universidade Federal do Ceará, Avenida Mister Hull 2977, Campus do Pici, Bloco 808, \\ Fortaleza, CE 60021-970, Brazil \\ ${ }^{3}$ Departamento Ecologia, Instituto de Biociências, Universidade de São Paulo, São Paulo, SP 05508-900, Brazil
}

Received 11 September 2015 - Revised 22 February 2016 - Accepted 8 March 2016

\begin{abstract}
Females of bee species can present a temporal specialized behavior in the food collection for their offspring. We studied the food of Euglossa townsendi immatures from nests established in trap-nests disposed in a hygrophilous forest in Brazil, between March 2010 and February 2012. The pollinic material remaining in the brood cells were acetolysed and identified by comparison with the pollen of plants that bloomed in the area during the study period. We identified 21 plant species belonging to 14 families in the provision. However, the results indicated that immature of Eg. townsendi feed preferentially on pollen of Miconia chamissois (Melastomataceae) found in $100 \%$ of the samples. Except for two nests, there was a similarity above $85 \%$ in the composition of the supply plants of the brood. We also found a high similarity between the pollinic contents of the cells of each nest. Our results suggest a temporal preference on M. chamissois .
\end{abstract}

bee diet / trophic niche / palinoecology / pollen / trap-nest / orchid bee

\section{INTRODUCTION}

Euglossini bees are best known by the behavior of males in collecting fragrances mainly from orchids (Ackerman 1983; Dodson et al. 1969; Dressler 1982; Roubik and Hanson 2004). However, the male bees also collect non-floral volatile compounds, which were produced in wood, fungi,

Electronic supplementary material The online version of this article (doi:10.1007/s13592-016-0441-y) contains supplementary material, which is available to authorized users.

Corresponding author: C. Silva, claudiainess@usp.brI. Silva, claudiainess@usp.br Manuscript editor: Klaus Hartfelder tree wounds, fruits (Ackerman 1983; Whitten et al. 1993), and feces (Eltz et al. 2007).

This behavior enables the attraction and capture of males in large numbers with the use of synthetic aromatic compounds similar to those present in orchids (Lopez 1963; Rebêlo and Cabral 1997). With this procedure, knowledge about the taxonomy, distribution, population dynamics, and structure of Euglossini communities has increased considerably in recent decades, but is based only on males (Braga and Garófalo 2003; Castro et al. 2013; Peruquetti et al. 1999). On the other hand, females are not attracted to chemical baits and combined with the difficulties of finding nests in the field (Cameron 2004; Dressler 1982; Garófalo et al. 1993) there is still little knowledge about the nesting habits and interactions of these 
bees with flowers both for the collection of food resources and for building their nests.

Studies on the interactions of Euglossini species with flowers are restricted to direct observations during floral visits (Lopes and Machado 1998; Rebêlo and Silva 1999; Singer and Sazima 2001) and studies have included the analysis of pollen grains sampled on the body of males and/or females (Ospina-Torres et al. 2015; RochaFilho et al. 2012; Silva et al. 2012a) or from brood cells (Arriaga and Hernández 1998; CortopassiLaurino et al. 2009; Otero et al. 2014; VillanuevaGutierrez et al. 2013).

Euglossa townsendi Cockerell is a species widely distributed in the Americas occurring from Mexico to northern Argentina (Moure et al. 2012; Rebêlo and Moure 1995) at altitudes ranging from 180 to $1050 \mathrm{~m}$ above sea level (Ramírez et al. 2002). Similar to other species of the genus, $E g$. townsendi nests in preexisting cavities (Garófalo et al. 1993; Gazola and Garófalo 2009; Peruquetti 1998) which has allowed obtaining nests of this species for studies on the nesting behavior and social structure (Augusto and Garófalo 2004). The study conducted by Augusto and Garófalo (2004) found that nests of Eg. townsendi are established by solitary females, which, after finishing their reproductive activities, remain in the nests. Foundations of nests occurred at a higher frequency in the warm/rainy season (September to April). When males emerge, they leave the nests; in turn, some females remain in the nests and start to reactivate it. In this reactivation, associations of two or more females may be formed. In this process, new cells are built and provisioned before eggs are laid. Alternatively, older cells can be reused. A sequence of successful reactivation processes provides long periods of duration of nests.

Considering that Eg. townsendi uses trapnests and displays reproductive activities at different times of the year (Augusto and Garófalo 2004), our objective was (i) to verify the diet breadth of the species, and (ii) evaluate the occurrence of specialization or generalization for certain pollen taxa in larval diets. In this study, we expected to find a diverse diet, but with a strong dominance of some botanical families or plant species, as reported by Arriaga and Hernández (1998),
Cortopassi-Laurino et al. (2009) and Villanueva-Gutierrez et al. (2013) for other species of Euglossini.

\section{MATERIAL AND METHODS}

\subsection{Study area}

The study was carried out at Private Reserve Toca da Paca (RTP), part of the Farm Boa Vista (21 $27^{\prime} 21.57^{\prime \prime}$ $\mathrm{S}$ and $\left.48^{\circ} 05^{\prime} 17.53^{\prime \prime} \mathrm{W}\right)$. The area is located at an average altitude of $510 \mathrm{~m}$, in the municipality of Guatapará, São Paulo State, Brazil (Figure 1). RTP is predominantly made up of hygrophilous forests (Castro et al. 2013). This vegetation is characterized by a permanently flooded soil (Toniato et al. 1998), and has the important function of protecting water sources (Teixeira et al. 2008). The region's climate type is Aw (Köppen 1948), with two well-defined seasons, one cold/dry and the other warm/rainy with average annual temperature ranging from 19.3 to $25.2^{\circ} \mathrm{C}$ and rainfall of $1183.6 \mathrm{~mm}$ (Castro et al. 2013) (Fig. 1 of supplementary material).

\subsection{Data collection}

As trap-nests (TN), we used bamboo canes (Figure 2a) of various lengths and diameters ranging from 1.0 to $2.0 \mathrm{~cm}$, with one end closed by the node itself. We used $64 \mathrm{TN}$ placed on iron supports and maintained at a height of $1.5 \mathrm{~m}$ above the ground. Two sampling sites, $200 \mathrm{~m}$ away from each other, were selected at the edge of the hygrophilous forest (Figure 2). Each site received 32 TN. Monthly, from August 2010 to July 2012, we inspected the TN and those found occupied and with all cells closed were taken to the laboratory where they were stored at room temperature until the emergence of individuals. When the nests were collected, we found one dead female inside the nest $\mathrm{N} 3$ while in the remaining nests no female was present.

One emerged male of each nest was sent to specialists for species identification and one male and one female of each nest was deposited in the collection of Solitary Bees and Wasps, Sector of Ecology, Departament of Biology of Faculdade de Filosofia, Ciências e Letras de Ribeirão Preto-USP.

After the emergence of individuals (Figure $2 \mathrm{~d}$ and e), we scraped the inner wall of each brood cell with the aid of a curette for removing residual pollen, consisting of 


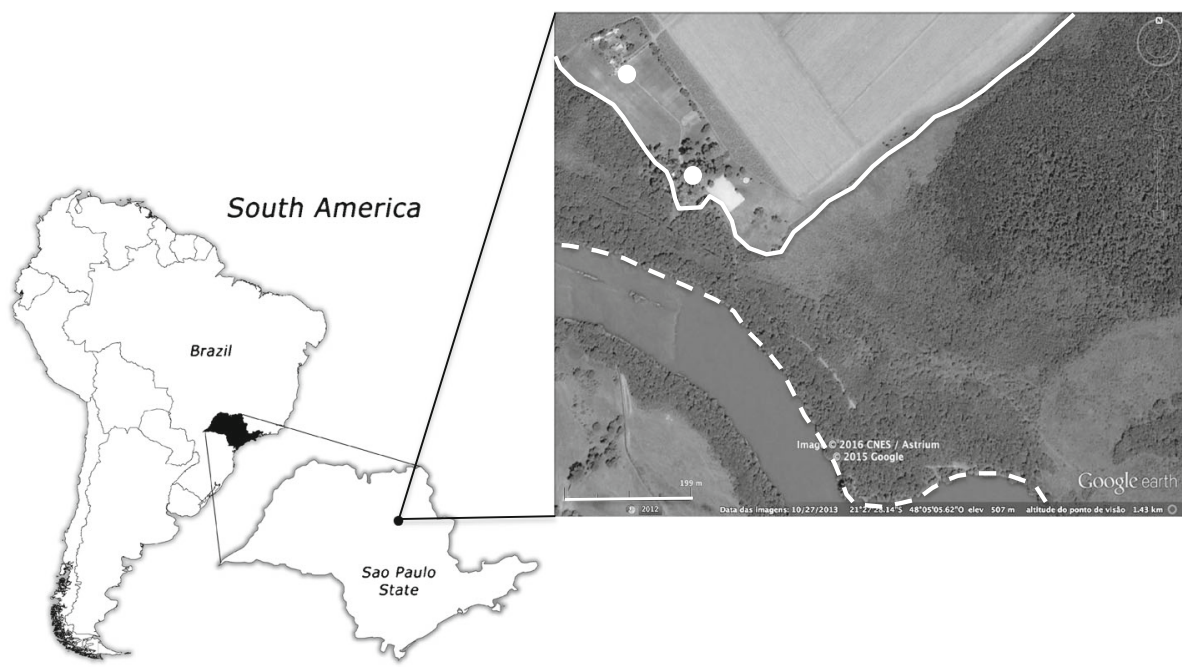

Figure 1. Location of the area where Euglossa townsendi nests were sampled in Guatapará, São Paulo State, Brazil. A solid line marks the area of native vegetation that makes up the hygrophilous forest. A dotted line marks the bank of the Mogi-Guaçu River. White dots represent the location of the trap-nests.

feces and pollen not consumed by the larvae (Figure $2 \mathrm{~b}$ and c). The pollen material of each cell was transferred separately to Falcon tubes containing $2 \mathrm{~mL}$ of $70 \%$ ethanol for at least $24 \mathrm{~h}$ (Silva et al. 2014a). After, the pollen material was centrifuged at $2000 \mathrm{rpm}$ for $10 \mathrm{~min}$ the ethanol was discarded. In the next step, we added $4 \mathrm{~mL}$ of glacial acetic acid to the pollen pelleted in the tubes and these were left to stand for $24 \mathrm{~h}$. Subsequently, the pollen material was subjected to acetolysis according to Erdtman (1960) and homogenized to ensure that the samples were representative of the diet. We embedded the samples in Kisser gelatin and sealed the slides with transparent varnish. These were then incorporated in the slide collection of the Palinoecology Laboratory of FFCLRP-USP (Silva et al. 2014a, b).

Parallel to this study, we demarcated an area of 2 ha from the installation point of the TN and sampled plant species in all vertical strata according Silva et al. (2012b) considering the habit or life form: arboreal, shrubby, herbaceous, liana, and epiphyte. Monthly, we studied the flowering phenology in the sampling area and recorded the number of individuals per species in blossom to estimate the availability of floral resources: pollen, nectar, and floral oil (Castro et al. unpubl. data).

Of the flowering species in the sampling area, we took the anthers and subjected them to acetolysis following the protocol proposed by Silva et al. (2014a).
This pollen collection was essential as it enabled a more accurate identification of the pollen found in the brood cells by comparing with the pollen material of plants flowering in the area throughout the study period. We also used specialized literature (Silva et al. 2010; Bauermann et al. 2013; Silva et al. 2014a) and online pollen database to identify the pollen grains sample in the brood cells (Roubik and Moreno 1991).

\subsection{Data analysis}

Qualitative analysis was carried out to identify the plant species found in the samples. We then calculated the mean and standard deviation of pollen types across brood cells per nest and plotted the data as box plot. After qualitative analysis, a quantitative analysis assessed the importance of each plant species identified in the larval diet. For that, the first 400 pollen grains in each sample were examined, as suggested by Montero and Tormo (1990). After counting, the percentage of each pollen type in a sample was calculated, and the pollen grains were classified according to Maurizio and Louveaux (1965): dominant pollen (>45\% of all grains counted in each sample), accessory pollen (15 to $45 \%$ ), important isolated 


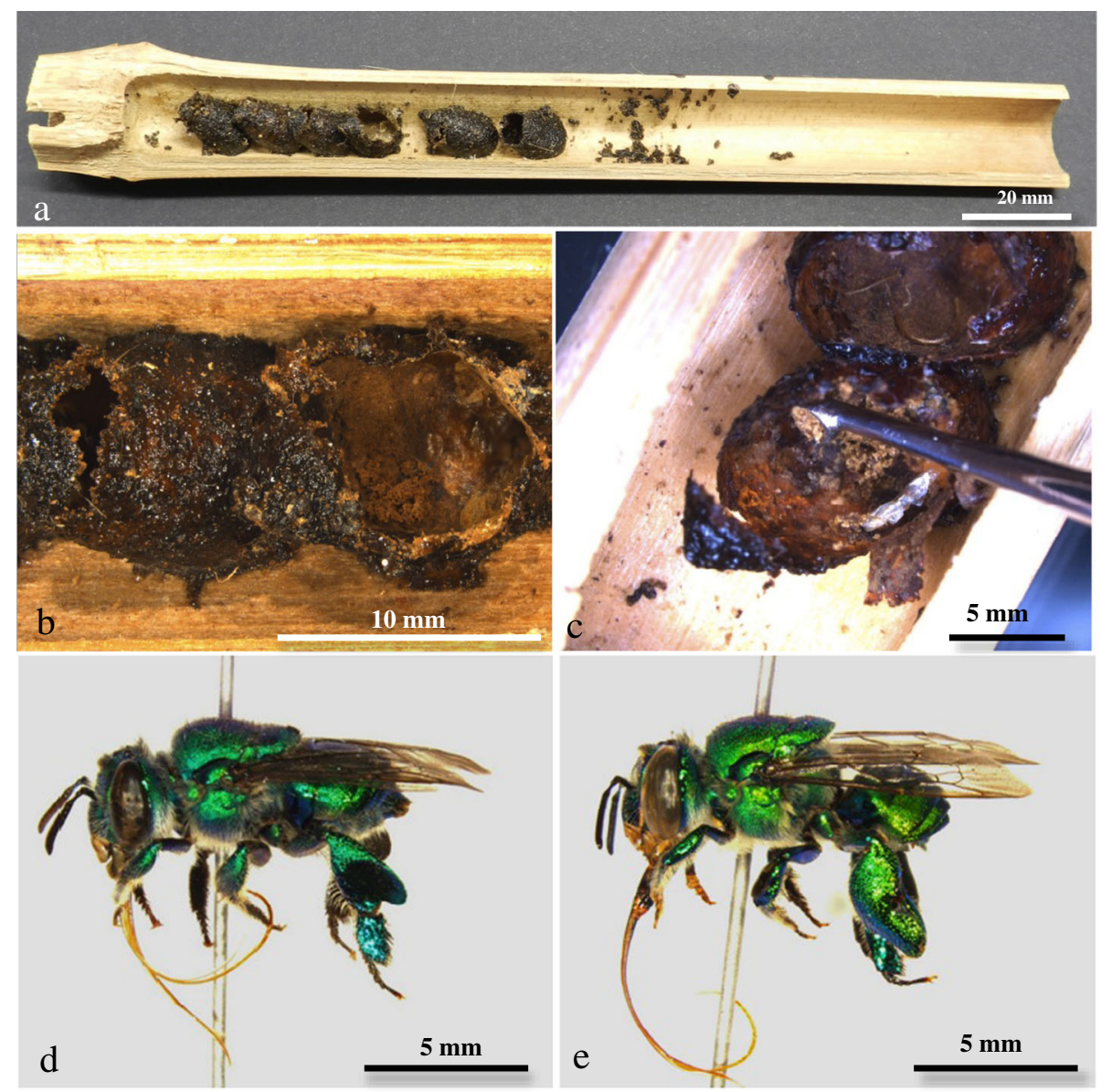

Figure 2. Nest of Euglossa townsendi after emergence of the bees. a Trap-nest made of bamboo cane with brood cells; b open brood cells; c collection of residual pollen from the brood cell; $\mathbf{d}$ female and $\mathbf{e}$ male of $E g$. townsendi.

pollen (3 to $15 \%$ ) and occasional isolated pollen $(<3 \%)$.

From the proportion data, we evaluated the trophic niche breadth corresponding to the feeding of a brood (nest) using the index of Shannon (1948) $\left(\mathrm{H}^{\prime}\right)$. To check the uniformity in the brood cells, we used the index of Pielou (1966) $\left(\mathrm{J}^{\prime}\right)$, and to analyze the dominance we applied the index of Berger-Parker (Magurran 2004) (D). We also evaluated the similarity in the brood cells using a cluster analysis using the Sørensen similarity coefficient (QS) (Sørensen 1948).

Analyses of diet breadth were performed using the statistical software PAST 2.17c (Hammer et al. 2001). The representation of the trophic interaction network as bipartite graphs (Dormann et al. 2008) was made using the bipartite package for R Development Core Team (2012).

\section{RESULTS}

Euglossa townsendi females established six nests in the study site: N1 in May 2010; N2, N3, and N4 in January 2011; and N5 in May and N6 in December 2011. The number of brood cells per nest ranged from 4 to 17, and N2 had the highest number of cells. In total, the six nests contained 54 brood cells.

We identified 21 species of plants used for feeding the immature brood, distributed into 14 families (Table I). Among these species, Miconia chamissois Naudin (Melastomataceae) (Fig. 2a of supplementary material) was present in all samples ( 6 nests and 54 cells), corresponding to over $75 \%$ of all pollen grains supplied as food for the brood. 


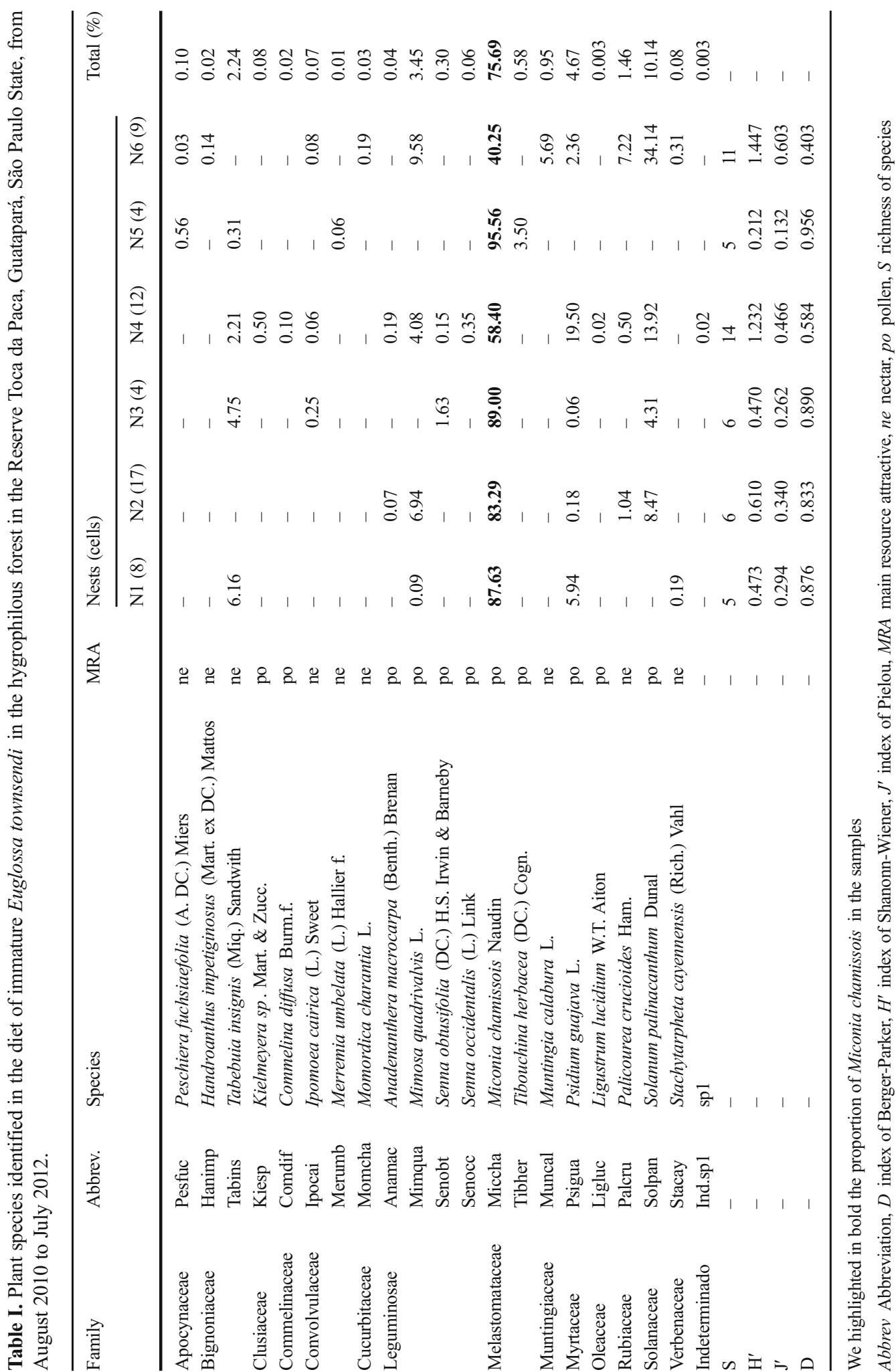


The second-most visited species for pollen collection was Solanum palinacanthum Dunal (Solanaceae) (Fig. 2b of supplementary material), representing $10.14 \%$ of pollen present in food of immature Eg. townsendi in the studied nests. Interestingly this species was not present in the nests established in May (N1 and N5). Of the plant species found in pollen provisions, nine are probably primarily used as sources of nectar (Table I). These plants may have been visited for the purpose of drinking nectar by the adult females, but the pollen grains nonetheless present in the brood food.

When we estimated the diversity, evenness, and dominance in the diet composition of immature, we observed variation among nests, with a low evenness in most of them. The nests with the highest richness had also higher diversity, in function of the low dominance of $M$. chamissois (Table I).

We identified between one to eight pollen types per brood cell among the studied nests (Figure 3). Except for N6 and N4, the other nests showed a similarity above $85 \%$ in the composition of plants used for provisioning brood cells. In the case of these two nests, M. chamissois pollen was not dominant, as mentioned above, but still significant

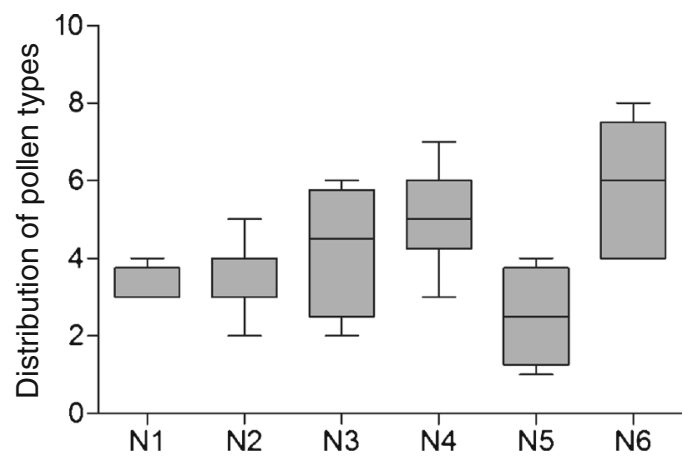

Figure 3. Distribution of pollen types identified in brood cells for each nest of Euglossa townsendi found in the hygrophilous forest in the Reserve Toca da Paca, Guatapará, São Paulo State, from August 2010 to July 2012. Boxplots show the median line within the boxes. The lower and upper hinges of the boxes indicate the interquartile range. The whiskers denote the range minimums and maximums values. (over $40 \%$ ). In these two nests, the diet of immatures was supplemented with pollen of S. palinacanthum (N4 and N6) and Psidium guajava L. (Fig. 2c of supplementary material) (N4) (Table I).

When we analyzed the diet of each immature within the same nest, that is, cells of the same female/mother, we found a high similarity in most nests. The nests that showed greater richness and diversity of plants, N4 (14 pollen types) and N6 (11 types), showed a similarity in the diet of individuals between 49-98 and 45-89\%, respectively (Table I).

Miconia chamissois was dominant in 43 out of 54 brood cells, representing more than $45 \%$ of the pollen grains provisioned, and in ten of these cells, the provision was monofloral (above $95 \%$ ) (Figure 4). In the remaning samples the pollen of M. chamissois was classified as accessory pollen (between 15 and $45 \%$ ) or isolated (10\%), in one single sample. In the first cell of nest 2 (N2CA), Mimosa quadrivalvis L. (Fig. 2d of supplementary material) was the dominant pollen; in N4CE P. guajava was the dominant pollen and in other three cells of the same nest (cell A, B, and H), S. palinacanthum was the dominant pollen (Figure 4). The latter pollen type was also the dominant in three cells of N6 (C, E, and F) (Figure 4).

\section{DISCUSSION}

We expected a more diverse assemblage of pollen types in the provisions of E. townsendi, as reported for other species of Euglossini (Arriaga and Hernández 1998; CortopassiLaurino et al. 2009; Villanueva-Gutierrez et al. 2013). However, the species richness of plants that made up the diet of immature Eg. townsendi was low (total of 21 plant species, varying from 5 to 14 in the six nests), when compared to that found for other species of Euglossini. Arriaga and Hernández (1998) recorded 67 plant species in nests of Euglossa atroveneta Dressler in Mexico. Cortopassi-Laurino et al. (2009) classified Euglossa annectans Dressler as polylectic by identifying 74 pollen types in its brood cells. Likewise, 45 pollen types were recorded in the nests of Euglossa viridissima Friese and Euglossa 


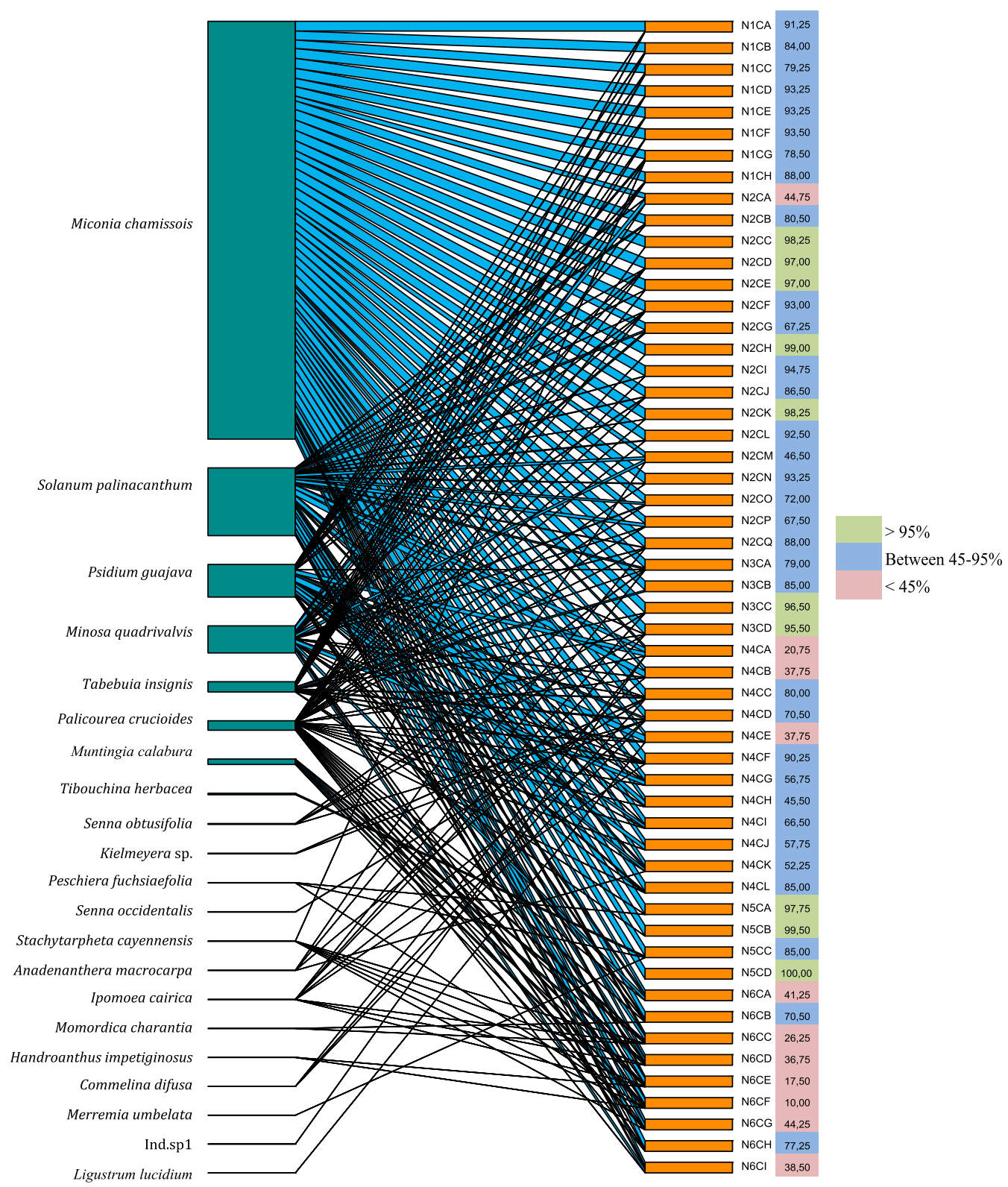

Figure 4. Individual diet of immature Euglossa townsendi. The meaning of abbreviations is presented in Table I. Orange rectangles are the pollen samples analyzed and represent the individual diet in each nest. Green rectangles represent plant species identified by means of the pollen grains provisioned in brood cells. Blue lines (links) represent the proportion of pollen grains of each plant species identified in the food provisioned in brood cells. The column next to the values in percentage indicates the representativeness of pollen of Miconia chamissois .

dilemma Bembé \& Eltz (Villanueva-Gutierrez et al. 2013). These values are certainly related to the number of nests examined and the number of females that worked in the nests. For these parameters, the values related to Eg. townsendi were lower than those for other species. Moreover, because the establishment of Eg. townsendi nests can occur at different times of the year 
(Augusto and Garófalo 2004), as also registered herein, and the phenology of flowering plants in the hygrophilous forest is diverse and temporally variable (Castro et al., unpubl. data), we clearly expected a wider pollen spectrum in the diet of the brood. Even though constructed in different periods (May 2010; January, May, and December 2011), the nests of Eg. townsendi showed a high similarity (over $80 \%$ ) in the composition and proportion of pollen types. This high similarity is likely due to the overall dominance of M. chamissois in brood cells.

Except for nest N6, M. chamissois was always dominant in the others. This species of Melastomataceae blooms from December to July, peaking in May, along with 78 other plant species, including two of the same family, Miconia jucunda (DC.) Triana and Tibouchina herbacea (DC.) Cogn. (Castro et al. 2013). In the same months in which nests were constructed, 55 other species of plants were flowering besides M. chamissois, providing nectar or pollen or both. Nevertheless, $M$. chamissois pollen was actively collected by females of Eg. townsendi during the construction of all 54 brood cells in the study site, and in some cases, it was the only plant used as a pollen source in the larval food (monofloral samples).

The low representativeness of $M$. chamissois in the diet of Eg. townsendi in the nest N6 may be because this nest was built in December, i.e., the beginning of flowering of $M$. chamissois (Castro et al. unpubl. data). Thus, the availability of fewer flowers or depletion of pollen therein lead the females to seek for other food source, in this case, S. palinacanthum, P. guajava, and $M$. quadrivalvis. Bee species specialized in collecting resources from certain plants can adjust their reproductive system to their phenology (Bartomeus et al. 2013; Rafferty and Ives 2011). This could explain the overlap of nesting activities of Eg. townsendi with the flowering period of M. chamissois .

A similar behavior of selection and preference of Euglossini for certain pollen species was reported by Silva et al. (2012a). These authors found that Eulaema nigrita Lepeletier, a large sized species with communal behavior, preferably collected pollen on flowers of Solanun lycocarpum A. St. Hil. In the absence of flowering of this species, El. nigrita started to forage pollen on Melastomataceae species, especially on Rhynchanthera grandiflora (Aubl.) DC.

Another aspect that may be associated with bee selectivity is the amount of pollen protein. Angiosperm species have pollen with 2.5 to $61 \%$ protein (Buchmann 1986) and in Melastomataceae species, the content can vary between 37 and $60 \%$ protein (Roulston et al. 2000). Furthermore, pollen digestibility can also determine the pattern of resource selection by floral visitors (Roulston and Cane 1999). Pollen of M. chamissois has a thin exine with three colporate and three pseudocolpus, which enhance the possibility of outflow of cytoplasm during the digestive process. In Brazil, no analyses were performed for some decades, with pollen from Euglossini nests, because it was believed that the bees break the pollen during foraging, making it difficult to identify the pollen material (Camillo, pers. comm.). Actually, Melastomataceae pollen grains are more sensitive than other species, and in the samples analyzed, we observed broken grains. But with technological advances in microscopy, pollen grains can now be identified at more specific levels even if they are broken (Silva et al. 2010; 2014b). Hence, comparisons can be made taking into consideration the presence of other pollen grains of the same species in the sample, by means of the characteristics of exine thickness, ornament, aperture type, and peculiarities of the exine structure (Erdtman 1952; Hesse et al. 2009; SalgadoLabouriau 1973; Silva et al. 2010, 2014b).

The low representativeness of Eg. townsendi visiting flowers, founding nests, and males attracted by the odor baits, leaves a gap in the interactions that this bee maintains with floral resources. In the study made by Rocha-Filho et al. (2012), who sampled pollen on the body of Euglossini bees in the Atlantic Forest, among the 68 individuals caught, only one female specimen was Eg. townsendi. They identified 105 plant species used by Euglossini bees and only two, Aechmea pectinata Baker (Bromeliaceae) and Sabicea cinerea Aubl. (Rubiaceae) were used by Eg. townsendi as nectar sources and three, Eugenia cf. fusca O. Berg (Myrtaceae), Tibouchina clavata (Pers.) Wurdack, and 
Tibouchina cf. pulchra Cogn. (Melastomataceae) were pollen sources. Other studies on the interactions of Euglossini bees with flowers, made through direct observation (Lopes and Machado 1998; Rebêlo and Silva 1999; Singer and Sazima 2001), reported the frequency of these bees on flowers of the families Leguminosae, Solanaceae, and Melastomaceae.

Of the few published studies on the botanical origin of the larval food, Arriaga and Hernández (1998) classified the feeding behavior of $E g$. atroveneta according to the sociality level. In parasocial nests, with more than one female working in the field, the bees were classified as polylectic, and in solitary nests, as oligolectic. According to the authors, the difference between the number of plant species in the diet may reflect the fact that parasocial nests remain active for a longer time, during which there are changes in plants flowering. Villanueva-Gutierrez et al. (2013) classified Eg. viridissima and Eg. dilem$m a$ as polylectic species, with selectivity for Solanum sp. and Physalis sp. (Solanaceae), as these two species together accounted for $77 \%$ of the total pollen in the nests. In the same way, Cortopassi-Laurino et al. (2009) considered Eg. annectans as polylectic, but registered high representativeness of species of Melastomataceae, Bromeliaceae, Ochnaceae, Leguminosae, and Myrtaceae among pollen grains.

Recently, Otero et al. (2014) found that Euglossa nigropilosa Moure is a specialist in collecting pollen from Melastomataceae species, and they classified it as oligolectic. This does not seem to be the case of the studied species, Eg. townsendi. Although a preference for pollen of M. chamissois has been shown, Eg. townsendi also collect pollen from other botanical families. It appears to be common that floral polylectic bees have a temporal preference for certain plant species, as found for Megalopta species (Smith et al. 2012) and social stingless bees that are generalists, collecting pollen and nectar from an array of plant species (Roubik 1989; Ramalho et al. 1990), but the workers can intensify collection at certain sources for an amount of time (Eltz et al. 2001; Faria et al. 2012; Aleixo et al. 2013). In any case, the family Melastomataceae seems to be an important pollen source for orchid bees. Even for those considered polylectic, pollen of Melastomataceae is always present (e.g., Eg. atroveneta ).

The interaction between Eg. townsendi and M. chamissois should be studied in more detail. This plant species has characteristics of a xenogamic reproductive system, that is, it depends on cross-pollination for fruiting (Caetano et al. 2013). Flowers of this plant are more specialized, with poricidal anthers and it needs vibration by the bee for "buzz pollination". Euglossa townsendi is able to perform this behavior and, thus, is a potential pollinator of $M$. chamissois flowers. At the same time, it showed floral constancy of the females for pollen collection from this plant, resulting in the predominance of $M$. chamissois also in the diet provided to the immatures.

\section{ACKNOWLEDGMENTS}

We thank Daniela de Azevedo Souza Defina, for allowing us to sample on her farm; the Guatapará municipal government (through Júlio Yoji Takaki) for providing the meteorological data. The study received financial support from FAPESP (process no. 2010/ 10285-4) and CAPES-PNPD (process no. 02958/090 ). A CAPES-Demanda Social sholarship was granted to MMNC via the Research Center on Biodiversity and Computing (BioComp). We thank Breno Magalhães Freitas and Alípio José de Souza Pacheco Filho for suggestions and comments on a previous version of this paper and we are grateful to the anonymous reviewers for their valuable contributions to improving the manuscript.

Forte prédominance du pollen de Miconia chamissois (Melastomataceae) dans les provisions de la cellule du couvain de l'abeille à orchidée Euglossa townsendi, dans l'état de São Paulo, Brésil

régime alimentaire / pollen / larve/ niche trophique / palynoécologie / nid-piège

Der Anteil von Miconia chamissois (Melastomataceae) Pollen überwiegt im Nahrungsvorrat der Brutzellen der Prachtbiene Euglossa townsendi im Staat São Paulo State, Brasilien

Bienennahrung / trophische Nische / Palinoökologie / Pollen / Nistfallen / Prachtbiene 


\section{REFERENCES}

Ackerman, J.D. (1983) Specificity and mutual dependency of the orchid-euglossine bee interaction. Biol. J. Linn. Soc. 20 (3), 301-314

Aleixo, K.P., Faria, L.B., Garófalo, C.A., Fonseca, V.L.I., Silva, C.I. (2013) Pollen collected and foraging activities of Frieseomelitta varia (Lepeletier) (Hymenoptera: Apidae) in an urban landscape. Sociobiology 60, 266-276

Arriaga, E.R., Hernández, E.M. (1998) Resources foraged by Euglossa atroveneta (Apidae: Euglossinae) at Union Juarez, Chiapas, Mexico. A palynological study of larval feeding. Apidologie 29 (4), 347-359

Augusto, S.C., Garófalo, C.A. (2004) Nesting biology and social structure of Euglossa (Euglossa) townsendi Cockerell (Hymenoptera, Apidae, Euglossini). Insectes Soc. 51 (4), 400-409

Bartomeus, I., Park, M.G., Gibbs, J., Danforth, B.N., Lakso, A.N., Winfree, R. (2013) Biodiversity ensures plant-pollinator phenological synchrony against climate change. Ecol. Lett. 16(11), 1331-1338

Bauermann, S.G., Radaeski, J.N., Evaldt, A.C.P., Queiroz, E.P., Mourelle, D., Prieto, A.R., Silva, C.I. (2013) Pólen nas Angiospermas: Diversidade e Evolução, p. 216. Editora da ULBRA, Canoas

Braga, A.K., Garófalo, C.A. (2003) Coleta de fragrâncias por machos de Euglossa townsendi Cockerell (Hymenoptera, Apidae, Euglossini) em flores de Crinum procerum Carey (Amaryllidaceae). In: Melo, G.A.R., Alves-dos-Santos, I. (eds.) Apoidea Neotropica: Homenagem aos 90 Anos Jesus Santiago Moure, pp. 201-207. UNESC, Criciúma

Buchmann, S.L. (1986) Vibratile pollination in Solarium and Lycopersicon: a look at pollen chemistry. In: D'Arcy, W.G. (ed.) Solanaceae: Biology and Systematics, pp. 237-252. Columbia Univ. Press, New York

Caetano, A.P.S., Simão, D.G., Carmo-Oliveira, R., Oliveira, P.E. (2013) Diplospory and obligate apomixis in Miconia albicans (Miconieae, Melastomataceae) and an embryological comparasion with its sexual congener M. chamissois. Plant Syst. Evol 299 (7), 1253-1262

Cameron, S.A. (2004) Phylogeny and biology of neotropical orchid bees (Euglossini). Ann. Rev. Entomol. 49, 377-404

Castro, M.M.N., Garófalo, C.A., Serrano, J.C., Silva, C.I. (2013) Temporal variation in the abundance of orchid bees (Hymenoptera: Apidae) in a neotropical hygrophilous forest. Sociobiology 60(4), 405-412

Cortopassi-Laurino, M., Zillikens, A., Steiner, J. (2009) Pollen sources of the orchid bee Euglossa annectans Dressler 1982 (Hymenoptera: Apidae, Euglossini) analyzed from larval provisions. Genet. Mol. Res. 8(2), 546-556

Dodson, C.H., Dressler, R.L., Hills, H.G., Adams, R.M., Williams, N.H. (1969) Biologically active compounds in orchid fragrances. Science 164 (3885), 1243-1249
Dormann, C.F., Gruber, B., Fründ, J. (2008) Introducing the bipartite package: analyzing ecological networks. R News 8, 8-11

Dressler, R.L. (1982) Biology of the orchid bee (Euglossini). Annu. Rev. Ecol. Syst. 13, 373-394

Eltz, T., Brühl, C.A., van der Kaars, S., Chey, V.K., Linsenmair, K.E. (2001) Pollen foraging and resource partitioning of stingless bees in relation to flowering dynamics in a Southeast Asian tropical rainforest. Insectes Soc. 48, 273-279

Eltz, T., Zimmermann, Y., Haftmann, J., Twele, R., Francke, W., Quezada-Euan, J.J.G., Lunau, K. (2007) Eufleurage, lipid recycling and the origin of perfume collection in orchid bees. Proc. R. Soc. B. 274 (1627), 2843-2848

Erdtman, G. (1952) Pollen morphology and plant taxonomy, Angiosperms. The Chronica Botanica Co., Walthan, Mass., Almquist Wiksell, Stochholm.

Erdtman, G. (1960) The acetolized method. A revised description. Sven. Bot. Tidskr. 54, 561-564

Faria, L.B., Aleixo, K.P., Garófalo, C.A., ImperatrizFonseca, V.L., Silva, C.I. (2012) Foraging of Scaptotrigona aff. depilis (Hymenoptera, Apidae) in an urbanized area: Seasonality in resource availability and visited plants. Psyche . doi:10.1155/2012/630628

Garófalo, C.A., Camillo, E., Serrano, J.C., Rebêlo, J.M.M. (1993) Utilization of trap nests by Euglossini species (Hymenoptera: Apidae). Rev. Bras. Biol. 53 (2), 177-187

Gazola, A.L., Garófalo, C.A. (2009) Trap-nesting bees (Hymenoptera: Apoidea) in forest fragments of the State of São Paulo. Brazil. Genet. Mol. Res. 8(2), 607-622

Hammer, Ø., Harper, D.A.T., Ryan, P.D. (2001) PAST: Paleontological statistics software package for education and data analysis. Palaeontologia Electronica 4 (1), 9 Available at http://palaeo-electronica.org/ 2001_1/past/issue1_01.htm

Hesse, M., Halbritter, H., Zetter, R., Weber, M., Buchne, R., Frosch-Radivo, A., Ulrich, S. (2009) Pollen Terminology - An Illustrated Handbook. Springer, Wien

Köppen, W. (1948) Climatologia: con un estudio de los climas de la tierra. Fondo de Cultura Econômica, México. 478

Lopes, A.V., Machado, I.C. (1998) Floral biology and reproductive ecology of Clusia nemorosa (Clusiaceae) in northeastern Brazil. Plant Syst. Evol. 213 (1), 71-90

Lopez, F.D. (1963) Two attractants for Eulaema tropica L. J. Econ. Entomol. 56 (4), 540

Magurran, A.E. (2004) Measuring Biological Diversity. Blackwell Science, Oxford

Maurizio, A., Louveaux, J. (1965) Pollens de Plantes Mellifères d'Europe. Union des groupements apicoles français, Paris

Montero, I., Tormo, R. (1990) Análisis polínico de mieles de cuatro zonas montañosas de Extremadura. Nacl. Asoc. Palinol. Leng. Esp. 5, 71-78

Moure, J.S., Melo G.A.R., Faria Jr., L.R.R. (2012) Euglossini Latreille, 1802, in: Moure, J. S., Urban, D. and Melo, G. A. R. (Eds.). Catalogue of Bees 
(Hymenoptera, Apoidea) in the Neotropical Region online version. Available at http:// www.moure.cria.org.br/catalogue

Ospina-Torres, R., Montoya-Pfeiffer, P.M., Parra-H, A., Solarte, V., Otero, J.P. (2015) Interactions networks and the use of floral resources by male orchid bees (Hymenoptera: Apidae: Euglossini) in a primary rain forests of the Chocó Region (Colombia). Rev. Biol. Trop. 63 (3), 647-658

Otero, J.P., Campuzano, A.M., Zuluaga, P.A., Caetano, C.M. (2014) Pollen carried by Euglossa nigropilosa Moure (Apidae: Euglossinae) at La Planada Nature Reserve, Nariño, Colombia. Bol. Mus. Entomol. Univ. Val. 15(1), 1-6

Peruquetti, R.C. (1998) Notes on adults of Euglossa townsendi (Apidae: Euglossini) reared from a trap nest. An. Soc. Entomol. Brasil 27 (2), 309-311

Peruquetti, R.C., Campos, L.A.O., Coelho, C.D.P., Abrantes, C.V.M., Lisboa, L.C.O. (1999) Abelhas Euglossini (Apidae) de áreas de Mata Atlântica: Abundância, riqueza e aspectos biológicos. Rev. Bras. Zool. 16 (Supl. 2), 101-118

Pielou, E.C. (1966) An Introduction to Mathematical Ecology. John Wiley, New York

R Development Core Team (2012) R: A Language and Environment for Statistical Computing. R foundation for Statistical Computing, Vienna

Rafferty, N.E., Ives, A.R. (2011) Effects of experimental shifts in flowering phenology on plant-pollinator interactions. Ecol. Lett. 14 (1), 69-74

Ramírez, S., Dressler, R.L., Ospina, M. (2002) Abejas euglosinas (Hymenoptera: Apidae) de la región neotropical: listado de especies con notas sobre su biología. Biota Colomb. 3 (1), 7-118

Ramalho, M., Kleinert-Giovannini, A., ImperatrizFonseca, V.L. (1990) Important bee plants for stingless bees (Melipona and Trigonini) and Africanized honeybees (Apis mellifera) in neotropical habitats: a review. Apidologie 21, 469-488

Rebêlo, J.M.M., Moure, J.S. (1995) As espécies de Euglossa Latreille do Nordeste de São Paulo (Apidae, Euglossinae). Rev. Bras. Zool. 12 (3), 445-446

Rebêlo, J.M.M., Cabral, A.J.M. (1997) Abelhas Euglossinae de Barreirinhas, zona do litoral da Baixada Oriental Maranhense. Acta Amaz. 27 (2), $145-152$

Rebêlo, J.M.M., Silva, F.S. (1999) Distribuição das abelhas Euglossini (Hymenoptera, Apidae) no Estado do Maranhão. Brasil. An. Soc. Entomol. Brasil 28(3), 389-401

Rocha-Filho, L.C., Krug, C., Silva, C.I., Garófalo, C.A. (2012) Floral resources used by Euglossini bees (Hymenoptera: Apidae) in coastal ecosystems of the Atlantic forest. Psyche . doi:10.1155/2012/934951

Roubik, D.W., Hanson, P.E. (2004) Orchid Bees of Tropical America: Biology and Field Guide. INBIO, San Jose

Roubik, D.W. (1989) Ecology and Natural History of Tropical Bees. University Press, Cambridge
Roubik, D.W., Moreno, E. (1991) Pollen and spores of Barro Colorado Island. Monographs in Systematic Botany, 36. Missouri Botanical Garden, St Louis

Roulston, T.H., Cane, J.H. (1999) Pollen nutritional content and digestibility for animals. Plant Syst. Evol. 222 (1), 187-209

Roulston, T.H., Cane, J.H., Buchmann, S.L. (2000) What governs protein content of pollen: pollinator preferences, pollen-pistil interactions, or phylogeny? Ecol. Monogr. 70 (4), 617-643

Salgado-Labouriau, M.L. (1973) Contribuição à Palinologia dos Cerrados. Acad. Bras. Ciências, Rio de Janeiro

Shannon, C.E.A. (1948) Mathematical theory of communication. Bell Syst. Technol. J. 27, 379-423

Silva, C.I., Imperatriz-Fonseca, V.L., Groppo, M., Bauermann, S.G., Saraiva, A.A., et al. (2014a) Catálogo Polínico das Plantas Usadas por Abelhas no Campus da USP de Ribeirão Preto. Holos, Ribeirão Preto

Silva, C.I., Imperatriz-Fonseca, V.L., Groppo, M., FerreiraCaliman, M.J., Garófalo, C.A. (2014b) Laboratório de palinoecología del departamento de biología de la Facultad de Filosofía Ciências y Letras de Ribeirão Preto, São Paulo. Brasil. Bol. Assoc. Latino. Paleob. Palinol. 14, 185-193

Silva, C.I., Ballesteros, P.L.O., Palmero, M.A., Bauermann, S.G., Evaldt, A.C.P., Oliveira, P.E. (2010) Catálogo polínico: Palinologia aplicada em estudos de conservação de abelhas do gênero Xylocopa no Triângulo Mineiro. EDUFU, Uberlândia

Silva, C.I., Bordon, N.G., Rocha Filho, L.C., Garófalo, C.A. (2012a) The importance of plant diversity in maintaining the pollinator bee, Eulaema nigrita (Hymenoptera: Apidae) in sweet passion fruit fields. Rev. Biol. Trop. 60 (4), 1553-1565

Silva, C.I., Araújo, G., Oliveira, P.E.A.M. (2012b) Distribuição vertical dos sistemas de polinização bióticos em áreas de cerrado sentido restrito no Triângulo Mineiro, MG, Brasil. Acta Bot. Bras. 56, 748-760

Singer, R.B., Sazima, M. (2001) Flower morphology and pollination mechanism in three sympatric Goodyerinae orchids from southeastern Brazil. Ann. Bot. 88(6), 989-997

Smith, A.R., López Quintero, I.J., Moreno Patiño, J.E., Roubik, D.W., Wcislo, W.T. (2012) Pollen use by Megalopta sweat bees in relation to resource availability in a tropical forest. Ecol. Entomol. 37, 309-317

Sørensen, T. (1948) A method of establishing group of equal amplitude in plant sociobiology based on similarity of species content and its application to analyses of the vegetation on Danish commons. Biol. Skr. 5, 134

Teixeira, A.D.P., Assis, M.A., Siqueira, F.R., Casagrande, J.C. (2008) Tree species composition and environmental relationships in a Neotropical swamp forest in Southeastern Brazil. Wetlands Ecol. Manage. 16, $451-461$ 
Toniato, M.T.Z., Leitão Filho, H.F., Rodrigues, R.R. (1998) Fitossociologia de um remanescente de floresta higrófila (mata de brejo) em Campinas. SP. Rev. Bras. Bot. 21, 197-210

Villanueva-Gutierrez, R., Quezada-Euan, J., Eltz, T. (2013) Pollen diets of two sibling orchid bee species,
Euglossa, in Yucatán, southern Mexico. Apidologie 44 (4), 440-446

Whitten, W.M., Young, A.M., Stern, D.L. (1993) Nonfloral sources of chemicals that attract male euglossine bees (Apidae, Euglossini). J. Chem. Ecol. 19, 3017-3027 